NBER WORKING PAPER SERIES

\title{
EFFECTS OF CHILD HEALTH ON PARENTS' RELATIONSHIP STATUS
}

Nancy E. Reichman

Hope Corman

Kelly Noonan

Working Paper 9610

http://www.nber.org/papers/w9610

\author{
NATIONAL BUREAU OF ECONOMIC RESEARCH \\ 1050 Massachusetts Avenue \\ Cambridge, MA 02138 \\ April 2003
}

This research was supported by Grant \#R01-HD-35301 from the National Institute of Child Health and Human Development. We are grateful for the valuable assistance of Jerry Bentley, William Greene, Michael Grossman, Stanley Henshaw, Robert Kaestner, Sara Markowitz, Jennifer Marogi, Sara McLanahan, David Ribar, Donald Wise, the Fragile Families Working Group, and the NBER Health Economics Group. The views expressed herein are those of the authors and not necessarily those of the National Bureau of Economic Research.

(C2003 by Nancy E. Reichman, Hope Corman, and Kelly Noonan. All rights reserved. Short sections of text not to exceed two paragraphs, may be quoted without explicit permission provided that full credit including Cnotice, is given to the source. 
Effects of Child Health on Parents' Relationship Status

Nancy E. Reichman, Hope Corman, and Kelly Noonan

NBER Working Paper No. 9610

April 2003

JEL No. J12, I12

\section{$\underline{\text { ABSTRACT }}$}

We use data from the national longitudinal Fragile Families and Child Wellbeing Study to estimate the effect of poor child health on father presence. We look at whether parents live in the same household 12-18 months after the child's birth and also at how their relationships changed along a continuum (married, cohabiting, romantically involved, friends, or not involved) during the same period. We find that having an infant in poor health reduces the likelihood that parents will live together and increases the likelihood that they will become less committed to their relationship, particularly among parents with low socioeconomic status.

Nancy E. Reichman

National Center for Children in Poverty

Mailman School of Public Health

Columbia University

154 Haven Ave.

NY, NY 10032

nr2058@columbia.edu

Kelly Noonan

Rider University

2083 Lawrenceville Road

Lawrenceville, NJ 08648

and NBER

knoonan@rider.edu
Hope Corman

Rider University

2083 Lawrenceville Road

Lawrenceville, NJ 08648

and NBER

corman@rider.edu 


\section{Introduction}

Approximately one third of all births in the United States in 2001 were to unmarried women. This does not mean that children are born without fathers present, however. Approximately two-fifths of children born out-of-wedlock have parents who are living together at the time of the birth, and another two-fifths have parents who, although not co-residing, are actively involved with one another (Bumpass \& Lu 2000, McLanahan et al. 2001).

Children born to unmarried parents are more likely than those born to married parents to experience spells of poverty as they grow up. They are also more likely to have health, behavior, and school problems. Having a seriously unhealthy child may be a further destabilizing force for these already "fragile" families because of the extra burden of caring for the child and the added demands on the family's financial resources. In this sense, unhealthy children born out-ofwedlock may be at even greater risk than their healthy peers.

A growing body of research indicates that low socioeconomic status in early childhood sets the stage for increasing disadvantages in both health and educational capital over the child's life course and can cause low socioeconomic status to persist for generations. Much less is known, however, about how child health affects a family's socioeconomic status. We use data from the national longitudinal Fragile Families and Child Wellbeing Study of mostly unwed parents to estimate how poor child health affects one potential human resource available to that child: father presence. The results provide important information about the relation between child health and family structure and help us understand the complex processes underlying children's health trajectories and human capital accumulation, particularly among families with low socioeconomic status. 


\section{Background}

The economics literature on marriage and relationship stability has evolved since the early 1970s, when Becker $(1973,1974)$ first examined marriage and childbearing within an economic framework. According to Becker, one of the main reasons for establishing a marital union is the utility that parents expect to derive from their children. Monogamous unions prevail when the population sex ratio is about unity, and when men and women do not differ greatly in wealth, ability, or other attributes. Both men and women want partners with the best attributes the "market" will allow, so high income, high-ability partners tend to marry each other. Because of this "positive assortative mating," income differences across families can persist for generations.

In response to the (then) increasing divorce rates, Becker, Landes \& Michael (1977) extended Becker's analysis to include marital dissolution. Because information up front about one's potential partner is costly and life involves uncertainty, individuals may become unpleasantly surprised with their spouse's actual characteristics and consider divorce. A divorce is more likely when the difference between the expected and actual quality of one's spouse is large. Similarly, an unexpected negative shock in the quality of one's children may lead to divorce because the utility from the union is lower than had been expected.

In a theoretical extension of Becker's work, Aiyagari, Greenwood \& Guner (2000) used a Nash bargaining model to simulate a marriage market and found that at any point in time, the lowest wage individuals tend to be unmarried; that public policies such as child support enforcement and welfare can affect both marriage and divorce; and that there is a high correlation in income across generations because children in low income households receive 
lower levels of human capital investment (and therefore have lower wages as adults) and because they are less likely to marry ( and therefore have lower household income).

Recent literature on relationship formation and childbearing has reflected two distinct trends: increases in the numbers of individuals who cohabit but do not marry and increases in the numbers of children born out of wedlock. Studies by Bumpass \& Raley (1995) and Bumpass \& $\mathrm{Lu}$ (2000) provide evidence of the dramatic increase in the number of children both born to and living with unmarried mothers. Willis (1999) posited that traditional families (with married partners having children and unmarried individuals remaining childless) will prevail in societies where men earn more than women and also outnumber them. In contrast, when women have assets or earnings that are high either in absolute terms or relative to those of men, and/or they outnumber men, then some fraction of low-income men will choose to father children out of wedlock and to multiple mothers who are the main or sole sources of support for their children. Since the 1970s, women's labor force participation and wages have grown far more quickly than those of men and there has been a growing share of young low-wage males who are incarcerated; both of these changes have coincided with increases in non-marital births.

Empirical studies have found that the wellbeing of women in cohabiting relationships (and their children) falls somewhere between that of their married and single counterparts. Lillard, Brien \& Waite (1995) found that those who cohabit before marriage are less likely to remain married because individuals who are more "dissolution-prone" self-select into cohabitation. Folk (1995) and Manning \& Smock (1997) found that mothers in cohabiting relationships fare better economically than do single mothers. Wu (1995), who used Canadian data to examine the effect of children on the stability of cohabiting relationships, found that children do stabilize cohabiting relationships, but not as strongly as they stabilize marriages. 
The vast literature on marriage, divorce, and child wellbeing indicates that children are best off in well-functioning, stable, high income, two-parent families. Both time and money investments in children are maximized when the child lives with biological parents who are strongly committed to each other. This is not the experience, however, of many American children. Children who grow up with only one biological parent are disadvantaged in many ways compared to children who grow up with both biological parents (McLanahan \& Sandefur 1994, Amato \& Keith 1991, Seltzer 1994, McLanahan \& Teitler 1999). They are less likely to graduate from high school and college, more likely to be idle (neither working nor in school), more likely to leave home early, more likely to become a teen or unmarried parent (for girls), more likely to divorce (given marriage), and more likely to have mental health problems in young adulthood.

According to economic theory, couples are less likely to stay together (or to marry or cohabit) if they have an unexpected negative event that lowers the value of the union. Children can be a major source of utility in a union, so the shock of a child in poor health or with a disability would be expected to lower the probability that the couple will form a union or stay together. There have been only three studies in the social science literature (Corman \& Kaestner 1992, Mauldon 1992, and Joesch \& Smith 1997) that have examined this issue. All three used the Child Health Supplement of the National Health Interview Survey, ${ }^{1}$ and all found that married couples are more likely to divorce when their child has a significant congenital health problem.

Mauldon distinguished between congenital and non-congenital problems, and also examined the effect of the child's age. She found stronger effects for congenital conditions than

\footnotetext{
${ }^{1}$ Corman \& Kaestner used the 1988 survey; Mauldon used 1981.
} 
for non-congenital conditions, and for children 6 to 9 years of age than for younger children. Corman \& Kaestner investigated the effects of congenital child health conditions on the relationship status of both married and unmarried mothers. They found that among unmarried mothers, those with unhealthy children were less likely to become married. Both Corman \& Kaestner and Mauldon found that once divorced, women with unhealthy children are no less likely to remarry. Taken together, findings from these studies indicate that children born with an adverse health condition are at elevated risk for poor adult outcomes both because of the condition itself and because they are more likely to grow up in households without both of their parents.

There are several limitations to these three studies. First, they all use the same data set. Second, the data relied on parent recall that could be up to fifteen years after the birth. Third, the studies did not account for cohabitation or other non-marital relationships between the parents. Fourth, there was very limited information on the father if he did not reside in the household. Fifth, none of these studies utilized recent econometric techniques to try to account for unobserved characteristics that might affect both child health and relationships. This study improves on all of these factors.

Recent literature has revisited the relationship between child health and socioeconomic status. Case, Lubotsky \& Paxson (2002) and Currie \& Stabile (2002) examined why children from families with low socioeconomic status have poor health and why the health differential between poor and non-poor children gets larger as they age. Case, Lubotsky \& Paxson presented a model in which a child's health deteriorates because of a health shock, the negative effects of which can be offset, at least in part, by parental investments in his or her health. Because 
wealthier parents will invest more in their children's health and because older children have been subjected to more shocks, the difference in child health between poor and non-poor children increases with age. Currie \& Stabile extended the analysis by investigating whether poor

children are less able to recover from a given health shock or whether they tend to experience a greater number of health shocks. They found that the latter explains the widening socioeconomic gap in child health with age.

Both Case, Lubotsky \& Paxson and Currie \& Stabile assumed that parents invest in their children, but that child health does not affect the parents' ability to invest (income). Given the research cited above showing that poor child health is related to marital disruption, this assumption may not be valid. If children born in poor health are more likely to grow up in singleparent families, they also are more likely to grow up in poverty. We investigate causality in this (reverse) direction by estimating the effect of the child's health at birth on the relationship status of the parents at one year, using a national sample of children at high risk for living in both single-parent households and poverty.

\section{Conceptual Model}

We begin with a simplified underlying behavioral model in which a parent's utility is a function of leisure $(\mathrm{L})$, goods consumed $(\mathrm{G})$, and the quality of his or her children $\left(\mathrm{C}_{\mathrm{Q}}\right)$ :

(1) $\mathrm{U}=\mathrm{U}\left(\mathrm{L}, \mathrm{G}, \mathrm{C}_{\mathrm{Q}}\right)$

Child quality is produced using a set of time inputs (resources) $\left(\mathrm{R}_{\mathrm{T}}\right)$, financial resources $\left(\mathrm{R}_{\mathrm{F}}\right)$, and the endowed health of the child at birth $(\mathrm{E})$ :

(2) $\mathrm{C}_{\mathrm{Q}}=\mathrm{C}_{\mathrm{Q}}\left(\mathrm{R}_{\mathrm{T}}, \mathrm{R}_{\mathrm{F}}, \mathrm{E}\right)$ 
The parent maximizes utility subject to the production function (2), as well as income and time constraints. From this constrained utility maximization, we can derive simplified reduced form demand functions for resources, where $\mathrm{Y}$ is income and $\mathrm{P}_{\mathrm{T}}$ and $\mathrm{P}_{\mathrm{F}}$ are the prices of time and financial resources, respectively:

(3) $\mathrm{R}_{\mathrm{j}}=\mathrm{R}_{\mathrm{j}}\left(\mathrm{Y}, \mathrm{P}_{\mathrm{T}}, \mathrm{P}_{\mathrm{F}}, \mathrm{E}\right)$, for $j=\mathrm{T}, \mathrm{F}$

In this paper, we estimate equation (3) for one type of human resource: father involvement. We characterize father involvement in terms of the commitment to the relationship with the mother, and not in terms of the quality of the relationship with the mother or the quality or quantity of time the father devotes to the child. To estimate this model, we need good measures or proxies for income, resource prices, and for the child's health. For income and prices, we use a set of parental characteristics including age, race/ethnicity, nativity, education, parity, and parents' relationship status at baseline. We describe our strategy for measuring child health below.

\section{Data}

The Fragile Families and Child Wellbeing Study follows a cohort of new parents and their children in 20 US cities (in 15 states). The study was designed to take a longitudinal look at the conditions and capabilities of new (mostly unwed) parents, the nature of their relationships, factors that push them together and those that pull them apart, and the long-term consequences for parents, children, and society of new welfare regulations, stronger paternity establishment, and stricter child support enforcement. The data, when weighted, are representative of births in US cities with populations over 200,000. Both the mothers and fathers were interviewed in the hospital at the time of the birth (fathers were interviewed by telephone or in-person outside of the 
hospital when the interview was not completed in the hospital), again when the child was one year old, and very recently, a third time when the child was three years old. A fourth follow-up interview with both parents is planned for when the child is five years old. ${ }^{2}$ Baseline interviews were conducted with 4898 mothers from 1998 to 2000; 89\% of the mothers who completed baseline interviews were re-interviewed when their children were between 12 and 18 months old.

The Fragile Families data are well suited for modeling relationship status and change because they include: (1) considerable detail about parents' relationships and living arrangements, and (2) sociodemographic factors (race/ethnicity, age, education, other children) of fathers as well as mothers. In terms of the former, each wave of the survey asks parents whether they are married to each other, cohabiting, romantically involved but not cohabiting, friends, or have little or no contact—and when applicable, if they have another partner.

\section{Measures}

The purpose of this paper is to estimate the effects of poor child health on parents' relationship status. Below, we describe the measures we use in our analyses and present summary statistics from the data. We exclude cases for which we do not have full information at both waves, resulting in a sample of 4,011 cases.

\section{Parents' relationships}

As discussed earlier, the majority of parents in the Fragile Families sample were unmarried at the time of the birth. In Table 1, we show parents' relationship status at the first follow-up by their relationship status at baseline (using mother reports). At baseline, there were

\footnotetext{
${ }^{2}$ Additional background on the research design of the Fragile Families and Child Wellbeing Study is available in Reichman et al. (2001).
} 
five relationship categories: married, cohabiting, romantically involved, friends, and little or no relationship. At follow-up, there is an additional category for separation or divorce.

In our multivariate analyses, we will look at the parents' relationship status at follow-up, given their relationship status at baseline. Table 1 shows that about half of the parents were cohabiting or married at baseline and that another quarter were romantically involved but not living together. Among those who cohabited at baseline, almost 30\% no longer lived together at follow-up, while about 15\% got married. Virtually all (almost 94\%) of the parents who were married at the time of the birth were still married at the time of the follow-up interview.

We also consider a broad measure of whether the parents' commitment to the relationship increased or remained the same (versus decreased) between baseline and follow-up (see Table 2). For example, consider a case in which the parents were romantically involved but not living together at baseline: If at 12 months they were "just friends," we consider the level of commitment to have decreased. If they remained romantically involved, lived together, or got married by 12 months, we consider their relationship commitment to have "stayed the same or improved." ${ }^{3}$ The commitment level of the parents, as we have characterized it, decreased in about a quarter of the cases. In general, the less committed the initial relationship, the greater the likelihood that the commitment level decreased.

In our models, we estimate two outcomes: (1) Whether the parents lived together (were married or cohabiting) at follow-up, and (2) Whether the relationship commitment stayed the same or improved between the baseline and follow-up (versus declined). For the latter, we exclude the 207 sets of parents who had no relationship at baseline.

\footnotetext{
${ }^{3}$ It is important to note that this measure is simplistic and that it is not a measure of the quality of the relationship.
} 


\section{Poor child health}

We consider a child to have poor health if at least one of the following criteria is met (all are from mothers' reports): the child weighed less than 4 pounds at birth, the mother reported at follow-up that the child had a disability, or the child had not started to walk or crawl by the time of the follow-up interview (12 to 18 months). According to our classification, about $6 \%$ the children in the sample had serious health problems. We used a stringent definition of low birthweight rather than the typical 5.5-pound cutoff in order to better identify cases of serious and chronic health problems (many of the heavier children do not experience long-term health problems). Our goal is to identify children with a serious health shock from birth.

\section{Other determinants of parents' relationship status}

In Table 3, we present the characteristics of the sample that we include in our models of parent's relationship status. In general, we use mother reports for information about the mother and father reports for information about the father. However, in cases where father's data are missing, we use mother reports about the father. Unless otherwise noted, all characteristics are measured at baseline. Both educational attainment and Medicaid (whether the birth was covered by Medicaid) are included as proxies for poverty status. With over half of the births covered by Medicaid, it is clear that a large proportion of the sample is poor or near-poor.

A measure unique to our data is whether the father has children with another partner. A father's response to having a child in poor health may depend on the quality and quantity of other children he has fathered (we do not have data on the quality of these children). One third of the fathers in the sample have at least one child with another partner-a finding consistent with recent literature on marriage and childbearing indicating that the lowest wage men tend to remain unmarried and father children with multiple partners. 
We take advantage of the longitudinal nature of our data by estimating models that control for the parental relationship at the time of the birth. We control for baseline relationship commitment in two ways: First, we include a variable indicating whether the parents lived together or were married at the baseline. Second, we include a variable indicating whether the father visited the hospital when the baby was born (almost $90 \%$ of the fathers visited during the mother's hospital stay).

Finally, we include state fixed-effects in our models to account for variations in parents' relationships that may be due to state policies and environments.

\section{Modeling Strategy}

We can express Equation (3) as follows:

(4) Parents' relationship $=f$ (Mother and father characteristics, child health, $\mu$ )

Here we consider father presence, represented by parents' relationship status or level of commitment, as a potential resource available to the child. The parents' relationship is a function of characteristics of the mother, characteristics of the father, and the child's health. The parental relationship function may also contain another set of factors, denoted by $\mu$, that are unobserved. Estimation of Equation (4) would be straightforward if the measured child health were truly random (exogenous). It is possible, however, that despite our best efforts at measuring true health shocks, we may capture non-random components of child health that are correlated with unobserved determinants of the parents' relationship $(\mu)$ that even the state fixed effects do not eliminate. If so, our measure of child health would be endogenous and its estimated effect on parents' relationship would be biased. 
Since we may not be completely successful at characterizing poor child health as a random event, we need to consider causes of possible endogeneity. We can imagine scenarios in which the unobserved determinants of child health and relationship status would be positively correlated, and others in which the correlation would be negative. For example, if the parents have strong "family values" that we cannot measure, they may be both less likely to abort an unhealthy or unwanted child and more likely to stay together, resulting in a positive correlation between poor child health and relationship stability. On the other hand, a parent with a high rate of time preference may be less likely than other parents to invest in both the health of the unborn child and in the parental relationship, resulting in a negative correlation between poor child health and relationship stability. Because we cannot be certain that child health is exogenous, we will model child health and its determinants as follows:

(5) Child Health $=g$ (mother \& father characteristics, prenatal \& perinatal health care availability) Equation (5) expresses the child's health as a function of parental characteristics, as well as the availability of health care inputs. It will also include an error term.

\section{Model specification for parents' relationship (Equation 4)}

We will let $\mathrm{RS}_{\mathrm{i}}{ }^{*}$ represent the underlying relationship status for individual $i$, conditional on the health of the child and other characteristics. In particular, assume that $R S_{i}{ }^{*}$ is a function of poor child health $\left(H_{i}\right)$ and mother and father characteristics, such that:

$$
R S_{i}^{*}=\beta_{H} H_{i}+\beta^{\prime} X_{i}+\varepsilon_{i}
$$


where $X_{i}$ is a vector of observed characteristics and $\varepsilon_{i}$ is the unobserved variation. Since $R S_{i}{ }^{*}$ is a latent variable, it is not directly observed. The observed outcome, $R S_{i}$, for individual $i$ is defined by the sign of the latent variable as follows:

$$
R S_{i}= \begin{cases}1 & \text { if } R S_{i}^{*} \geq 0 \\ 0 & \text { otherwise }\end{cases}
$$

Model specification for child health (Equation 5)

We assume that the probability that a child has poor health, $H_{i}{ }^{*}$, is a linear function of parent characteristics and prenatal and perinatal health care availability:

$$
H_{i}^{*}=\beta_{Z} Z_{i}+u_{i}
$$

where $Z_{i}$ is a vector of observed characteristics and $u_{i}$ is the error term for individual $i$. The data for $Z_{i}$ will be taken primarily from the baseline survey.

Since $H_{i}{ }^{*}$ is a latent variable, it is not directly observed. The observed health, $H_{i}$, for individual $i$ is defined by the sign of the latent variable as follows:

$$
H_{i}= \begin{cases}1 & \text { if } H_{i}^{*} \geq 0 \\ 0 & \text { otherwise }\end{cases}
$$

We assume that both of the error terms, $u_{i}$ and $\varepsilon_{i}$, are normally distributed. In addition, we normalize the variance of the disturbance terms to one and we allow for these error terms to be correlated. Therefore, the covariance matrix is given by:

$$
\Sigma=\left[\begin{array}{ll}
1 & \rho \\
\rho & 1
\end{array}\right]
$$

We use a bivariate probit model specification in which we estimate both poor child health and the parents' relationship. If the correlation between the error terms $(\rho)$ is not significantly different from zero, it implies that poor child health is exogenous and that a standard probit is the 
more appropriate model. For this two-equation system to be identified, we must impose either exclusion restrictions or set restrictions on the correlation coefficient of the error terms in the two equations (see Altonji et al. 2000).

We use three identifiers in estimating poor child health: the number of obstetricians/gynecologists in 1996 per 10,000 women age 15 to 44 in the city of the child's birth, the presence (or lack thereof) of a Level III neonatal intensive care unit in the hospital where the baby was delivered, and the number of abortion providers performing more than 400 abortions in 1996 in the county or counties corresponding to the city in which the child was born. ${ }^{4}$ The first two are proxy measures for access to care, and abortion availability may be related to the wantedness of the child (see, for example, Grossman \& Joyce 1990, which showed that children who are more wanted tend to receive greater levels of prenatal care). There is considerable variation in the availability of these inputs: ob/gyns ranged from 7 to 41 and abortion providers ranged from 2 to 35 .

For the identifiers to be valid, they must satisfy two conditions. Condition \#1: They must be significant predictors of poor child health. Condition \#2: They must be uncorrelated with relationship status of the parents.

\section{Results}

In Tables 4(a) and 5(a), we present the results from models in which we estimate the effect of poor child health on whether the parents lived together at follow-up and whether the relationship commitment maintained/increased, respectively. In the probit models, child health is

\footnotetext{
${ }^{4}$ Data on ob/gyns were obtained from the American Medical Association; population data were obtained from the 2000 US Census; data on Level III NICUs were collected by the authors; data on abortion providers were compiled for the authors by the Alan Guttmacher Institute.
} 
assumed to be exogenous to relationship status and in the bivariate probit models, we allow for the possible endogeneity of child health. In Tables 4(b) and 5(b) we present probit and bivariate probit estimates of child health. In all models, the standard errors are corrected for city clustering of observations using the Huber-White method. Because the coefficients in these models are not easy to interpret, we also present marginal effects.

According to the probit specification in Table 4(a), poor child health significantly reduced the probability that the parents lived in the same household at follow-up. The marginal effect indicates that a having a child in poor health reduced the probability that the parents were cohabiting or married at follow-up by approximately 9 percentage points. The bivariate probit model also indicates a significant negative effect of poor child health on parents' living together at follow-up, with the estimated marginal effect more than triple that from the single-equation model. We test the hypothesis of zero correlation between the error terms in equations (6) and (7); as shown in Table 4(a), $\rho$ is positive and significant at the $4 \%$ level. The positive sign of $\rho$ is consistent with the "family values" hypothesis.

To assess the strength of the correlation between our identifiers and poor child health (Condition \#1), we test the joint significance of the three identifiers in the bivariate probit child health model. As shown in Appendix Table 1, Wald tests indicate that the three identifiers (ob/gyns, Level III NICUs, and abortion providers) are jointly significant at the $1 \%$ level in both the probit and bivariate specifications.

To ensure that our identifiers are excludable from the outcome equation (uncorrelated with the relationship status of the parents) (Condition \#2), we follow Rashad \& Kaestner (2003) and use a just-identified bivariate probit with the other two identifiers as predictors in the relationship equation. We perform Wald tests to determine whether the two identifiers are jointly 
significant in predicting whether the parents lived together at follow-up. If they are jointly significant, then they are not valid identifiers. ${ }^{5}$ The results, presented in Appendix Table 2, indicate that no matter which pair of identifiers we use to perform the test, we satisfy Condition $\# 2$ in that the identifiers are not jointly significant predictors of the relationship.

In Table 4(a), the signs of the coefficients for predictors other than child health are as expected. The likelihood that the parents were cohabiting or married at follow-up is positively associated with education of the mother, the father's age, the baby's parents having resided together at baseline, and the father having visited in the hospital. Women who are foreign-born were more likely to live with the baby's father at follow-up. When the baby's father had one or more children with another partner, the parents were less likely to live together.

The results in Table 5(a) indicate that having a child with a serious health problem significantly decreased the likelihood that the parents' level of relationship commitment stayed the same or increased. The marginal effect of poor child health on relationship change is about 7 percentage points in the single-equation probit, which is very similar to the corresponding result in Table 4(a) and provides further evidence that having a child in poor health reduces the stability of the child's living arrangements. Again, the marginal effect of poor child health in the bivariate probit model is more than triple that from the single-equation probit.

As shown in Table 5(a), $\rho$ is not statistically significant—even at the $10 \%$ level, indicating that the single-equation probit is appropriate in this case, provided that Conditions \#1 and \#2 are met. Indeed, the test results (presented in Appendix Tables 1 and 2) indicate that the identifiers are valid. Overall, the effects of the other predictors on change in relationship

\footnotetext{
${ }^{5}$ According to Bollen, Guilkey \& Mroz (1995) it does not matter which pair of identifiers are included. To be cautious, we performed the test using each possible pair. As expected, the results did not vary by pair.
} 
commitment are similar to those found in Table 4(a). Note, again, that the father having had children with another partner significantly reduced the relationship commitment.

These results — that having a child in poor health significantly reduces relationship stability of the parents - are consistent with, but expand upon and update, those of previous studies by Corman \& Kaestner (1992), Mauldon (1992) and Joesch \& Smith (1997). As indicated earlier, all three of these studies used the same data set (the Child Health Supplement of the National Health Interview Survey, 1981 or 1988) to examine the effect of poor child health on divorce among married parents. ${ }^{6}$ Corman $\&$ Kaestner (1992) found that white women who were married at the time of the birth were, on average, about three percentage points more likely to become unmarried if their child had a physical health condition. These results pertained to children who were between 3 and 15 years of age and the divorce could have taken place at any point during their lives. Mauldon (1992) examined the risk of divorce by child's age range and found that a complicated delivery increased the risk of divorce among parents with children between the ages of 0 and 2 by approximately two percentage points (evaluated at the mean). Joesch \& Smith presented a range of results for different definitions of child disability; the finding most relevant to the current study was that low birthweight was associated with a one percentage point increase in the risk of divorce. Similar to Corman \& Kaestner's analysis, their results pertained to children who were at least two and up to 17 years of age and the divorce could have taken place at any point during those years.

The fact that we have found larger effects than these previous studies had is not surprising, given that we examined a group of mostly unwed parents, who are at high risk for

\footnotetext{
${ }^{6}$ Corman \& Kaestner also looked at whether poor child health affected the likelihood of marriage among mothers who were unmarried when the child was born. Since remarriage could have been to anyone-not necessarily to the baby's father - these particular results are not comparable to ours.
} 
relationship instability to begin with (Graefe \& Lichter 1999). Moreover, the mothers in our sample gave birth decades later - after dramatic increases in non-marital birth rates, abortion rates, women's labor force participation rates, and male incarceration rates, and following a period of major welfare reform, widespread changes in health care delivery systems, and prolonged economic prosperity.

Next, we take advantage of the functional form of our model to illustrate, based on the probit results from Table 5(a), the marginal effects of poor child health on relationship change for two hypothetical "average" sets of parents - one likely to have had low income (both mother and father had less than a high school degree and the birth was financed by Medicaid) and the other likely to have had relatively high income (both parents were college graduates and the birth was not paid for by Medicaid). This comparison, presented in Figure 1, assumes mean values for all variables other than education, Medicaid, and child health.

Figure 1 reveals the following: First, having a child in poor health results in decreased in relationship commitment among parents at both ends of the economic spectrum. Second, children born into families with low socioeconomic status are far more likely than those from higher income families to experience a decline in parental commitment, regardless of their health status. Given a healthy child, the probability of the average low-income mother's relationship with the father staying the same or improving is .70, compared to .90 for the average higher income mother. Third, the negative effect of poor child health on relationship commitment is larger in magnitude when the parents have low socioeconomic status. The marginal effects from our models indicate a greater likelihood of deterioration in relationship commitment when the child has poor health; the illustrative comparison in Figure 1 indicates that this effect is magnified substantially when the parents are of low socioeconomic status. 


\section{Conclusion}

Past research has found that poor child health is related to marital dissolution, placing unhealthy children at "double jeopardy" for future health and economic outcomes, and that nonmarital relationships are more volatile than marital relationships in that they are more likely to end and to have shorter durations. In this study, we have tied together these literatures by examining the effects of poor child health on parental relationships using a new national sample of mostly unmarried parents. We found that within a very short period of time $(12-18$ months after the birth), having a child with poor health decreases the level of commitment in the parents' relationship, suggesting that not only will their children be at increased risk, but that the period of decreased paternal attachment they experience will be even longer than previous studies have indicated.

Our results have important implications for our understanding of the processes underlying the intergenerational transmissions of health and poverty. Recent studies have highlighted the role of socioeconomic status in determining health and economic trajectories of children as they age. In particular, poor children receive lower levels of health investments that can buffer the effects of adverse health shocks. This recent line of research has assumed that the causality runs in one direction, from income to health, and that child health does not affect the parents' income. Our results indicate that poor child health may affect parental income through parental relationships, suggesting that child health and income may interactively and jointly determine children's health and economic trajectories. 


\section{References}

Aiyagari, S. R., J. Greenwood and N. Guner (2000). "On the State of the Union." Journal of Political Economy 108(2): 213-244.

Altonji, J. G., T. E. Elder and C. R. Taber (2000). "Selection on Observed and Unobserved Variables: Assessing the Effectiveness of Catholic Schools." NBER. Working Paper: 7831.

Amato, P. R. and B. Keith (1991). "Parental Divorce and Adult Wellbeing: A meta-analysis." Psychological Bulletin 110: 26-46.

Becker, G. S. (1973). "A Theory of Marriage: Part I." The Journal of Political Economy 81(4): 813-846.

------ (1974). "A Theory of Marriage: Part II." The Journal of Political Economy 82(2): S11S26.

Becker, G. S., E. M. Landes and R. T. Michael (1977). "An Economic Analysis of Marital Instability." The Journal of Political Economy 85(6): 1141-1188.

Bollen, K. A., D. K. Guilkey and T. A. Mroz (1995). "Binary outcomes and endogenous explanatory variables: Tests and solutions with an application to the demand for contraceptive use in Tunisia." Demography 32(1): 111-131.

Bumpass, L. and H. H. Lu (2000). "Trends in Cohabitation and Implications for Children's Family Contexts in the United States." Population Studies 54(1): 29-41.

Bumpass, L. and R. K. Raley (1995). "Redefining Single-Parent Families: Cohabitation and Changing Family Reality." Demography 32(1): 97-109.

Case, A., D. Lubotsky and C. Paxson (2002). "Economic Status and Health in Childhood: The Origins of the Gradient." American Economic Review 92(5): 1308-1334.

Corman, H. and R. Kaestner (1992). "The Effects of Child Health on Marital Status and Family Structure." Demography 29(3): 389-408.

Currie, J. and M. Stabile (2002). "Socioeconomic Status and Health: Why is the relationship stronger for older children?" NBER. Working Paper: 9098.

Folk, K. F. (1995). Single Mothers in Various Living Arrangements: Differences in Economic and Time Resources. School of Family Resources and Consumer Sciences. Madison, University of Wisconsin: 22.

Graefe, D.R. and D. T. Lichter (1999). "Life Course Transitions of American Children: Parental Cohabitation, Marriage and Single Motherhood," Demography 36: 205-217. 
Grossman, M. and T. Joyce (1990). "Unobservables, Pregnancy Resolutions, and Birthweight Production Functions in New York City." Journal of Political Economy 98: 983-1007.

Joesch, J. M. and K. R. Smith (1997). "Children's Health and Their Mothers' Risk of Divorce or Separation." Social Biology 44(3-4): 159-169.

Lillard, L. A., M. J. Brien and L. J. Waite (1995). "Premarital Cohabitation and Subsequent Marital Dissolution: A Matter of Self-Selection?" Demography 32(3): 437-57.

Manning, W. D. and P. J. Smock (1997). "Children's Living Arrangements in Unmarried-Mother Families." Journal of Family Issues 18(5): 526-544.

Mauldon, J. (1992). "Children's Risks of Experiencing Divorce and Remarriage: Do Disabled Children Destabilize Marriages?" Population Studies 46(2): 349-62.

McLanahan, S., Garfinkel, I., Reichman, N., and J. Teitler, J (2001). "Unwed Parents or Fragile Families? Implications for Welfare and Child Support Policy." In Lawrence Wu and Barbara Wolfe (eds.) Out of Wedlock: Causes and Consequences of Non-Marital Fertility. NY, NY: Russell Sage Foundation, pp. 202-228.

McLanahan, S. S. and G. D. Sandefur (1994). Growing Up With a Single Parent. Cambridge, MA: Harvard University Press.

McLanahan, S. S. and J. O. Teitler (1999). "The Consequences of Father Absence." In Parenting and Child Development in Nontraditional Families. Edited by M. Lamb. Mahwah: Lawrence Erlbaum Associates Inc. Publishers.

Rashad, I. and R. Kaestner (2003). "Teenage Sex, Drugs and Alcohol: Risky Behaviors and Risky Econometric Methods." Unpublished working paper.

Reichman, N. E., J. O. Teitler, I. Garfinkel and S. S. McLanahan (2001). "Fragile Families: Sample and Design." Children and Youth Services Review 23(4/5): 303-326.

Seltzer, J. A. (1994). "Consequences of Marital Dissolution for Children." Annual Review of Sociology 20: 235-266.

Willis, R. J. (1999). "A Theory of Out-of-Wedlock Childbearing." Journal of Political Economy 107(6): S33-64.

Wu, Z. (1995). "The Stability of Cohabitation Relationships: The Role of Children." Journal of Marriage \& Family 57(1): 231-237. 
Table 1: Distribution of Cases by Parent's Relationship at Baseline \& Follow-Up (mother reports)

Relationship Status at 12-months (row percentages and counts)

\begin{tabular}{|c|c|c|c|c|c|c|c|}
\hline $\begin{array}{l}\text { Relationship } \\
\text { Status at } \\
\text { birth: }\end{array}$ & Married & Cohabiting & Romantic & Friends & $\begin{array}{c}\text { No } \\
\text { Relationship }\end{array}$ & $\begin{array}{c}\text { Separated/ } \\
\text { Divorced }\end{array}$ & Total \\
\hline Married & $\begin{array}{c}94 \% \\
978\end{array}$ & $\begin{array}{c}1 \% \\
11\end{array}$ & $\begin{array}{c}<1 \% \\
3\end{array}$ & $\begin{array}{c}<1 \% \\
1\end{array}$ & $\begin{array}{c}<1 \% \\
1\end{array}$ & $\begin{array}{c}4 \% \\
42\end{array}$ & 1036 \\
\hline Cohabiting & $\begin{array}{c}15 \% \\
223\end{array}$ & $\begin{array}{c}56 \% \\
848\end{array}$ & $\begin{array}{l}9 \% \\
129\end{array}$ & $\begin{array}{c}11 \% \\
163\end{array}$ & $\begin{array}{l}8 \% \\
127\end{array}$ & $\begin{array}{c}1 \% \\
16\end{array}$ & 1506 \\
\hline Romantic & $\begin{array}{c}6 \% \\
59\end{array}$ & $\begin{array}{c}25 \% \\
257\end{array}$ & $\begin{array}{c}23 \% \\
239\end{array}$ & $\begin{array}{c}25 \% \\
256\end{array}$ & $\begin{array}{c}20 \% \\
210\end{array}$ & $\begin{array}{c}1 \% \\
14\end{array}$ & 1035 \\
\hline Friends & $\begin{array}{c}<1 \% \\
1\end{array}$ & $\begin{array}{r}6 \% \\
14\end{array}$ & $\begin{array}{r}6 \% \\
13\end{array}$ & $\begin{array}{c}45 \% \\
103\end{array}$ & $\begin{array}{c}40 \% \\
91\end{array}$ & $\begin{array}{c}2 \% \\
5\end{array}$ & 227 \\
\hline $\begin{array}{l}\text { Rarely/Never } \\
\text { Talk }\end{array}$ & $\begin{array}{c}<1 \% \\
2\end{array}$ & $\begin{array}{c}5 \% \\
11\end{array}$ & $\begin{array}{c}6 \% \\
12\end{array}$ & $\begin{array}{c}26 \% \\
53\end{array}$ & $\begin{array}{c}60 \% \\
125\end{array}$ & $\begin{array}{c}2 \% \\
4\end{array}$ & 207 \\
\hline Total & $\begin{array}{l}31 \% \\
1263\end{array}$ & $\begin{array}{l}28 \% \\
1141\end{array}$ & $\begin{array}{c}10 \% \\
396\end{array}$ & $\begin{array}{c}14 \% \\
576\end{array}$ & $\begin{array}{l}14 \% \\
554\end{array}$ & $\begin{array}{c}2 \% \\
81\end{array}$ & 4011 \\
\hline
\end{tabular}


Table 2: Changes in Relationships between Baseline and Follow-up

Direction of Change in Commitment Level:

\begin{tabular}{lccc} 
Relationship Status & Up & Same & Down \\
\cline { 2 - 4 } Married & N/A & $94 \%$ & $6 \%$ \\
Cohabiting & $15 \%$ & $56 \%$ & $29 \%$ \\
Romantic & $31 \%$ & $23 \%$ & $46 \%$ \\
Friends & $12 \%$ & $45 \%$ & $42 \%$ \\
Rarely/Never Talk & $38 \%$ & $62 \%$ & N/A
\end{tabular}

Note: The five relationship categories are listed in the first column from most to least committed. A movement "up" might be, for example, from Romantic to Cohabiting. 
Table 3: Sample Characteristics

Relationship With Father Same or Improved Proportions (unless indicated otherwise) $n=4011$ $\mathrm{n}=3804$

$\begin{array}{ll}\text { Parents Lived Together at Follow-up } & .60\end{array}$

Child In Poor Health $\quad .06$

Mother's Characteristics:

Immigrant

Age (years)

25

25

Less than High School*

High School Grad

.32

.32

Some College

College Grad

.25

Medicaid

.12

Attends Religious Services Several Times/Month

.60

Hispanic

.39

Non-White/ Non-Hispanic

.27

White Non-Hispanic*

.51

Lived with Both Parents at Age 15

.23

Time Has Known Father (months)

.43

Lived with Baby's Father at Baseline

60

Male Child

Male Child

Other Children (number)

Father's Characteristics:

Age (years)

Less than High School*

High School Grad

Some College

College Grad

Hispanic

Non-White/ Non-Hispanic

White Non-Hispanic*

Visited Hospital at Birth

Has 1 Child w/ Another Partner

Has $>1$ Child w/ Other Partner

\section{Identifiers}

\# of Ob/Gyns per 10,000 Women in City

\# Abortion Providers in County 
Table 3: Sample Characteristics (continued)

\begin{tabular}{lcc}
\hline States: & $\mathbf{n = 4 0 1 1}$ & $\mathbf{n = 3 8 0 4}$ \\
\hline California & .12 & .12 \\
Texas & .16 & .16 \\
Maryland & .07 & .07 \\
Michigan & .07 & .07 \\
New Jersey & .07 & .07 \\
Pennsylvania & .09 & .09 \\
Virginia & .09 & .09 \\
Indiana & .07 & .07 \\
Wisconsin & .07 & .07 \\
New York & .07 & .07 \\
Massachusetts & .02 & .02 \\
Tennessee & .02 & .02 \\
Illinois & .03 & .03 \\
Florida & .02 & .02 \\
Ohio* & .02 & .02 \\
\hline
\end{tabular}

Notes:

${ }^{*}$ Excluded categories in analyses

Standard deviations in parentheses 
Table 4(a): Probit and Bivariate Probit Estimates of the Effect of Poor Child Health on Whether Parents Lived Together at Follow-up ( $n=4011)$

\begin{tabular}{|c|c|c|c|c|}
\hline \multirow{3}{*}{ Child is in Poor Health } & \multicolumn{2}{|c|}{ Probit } & \multicolumn{2}{|c|}{$\begin{array}{c}\text { Bivariate } \\
\text { Probit }\end{array}$} \\
\hline & Coefficient & Marginal Effect & Coefficient & Marginal Effect \\
\hline & $\begin{array}{l}-.22^{* *} \\
(.11)\end{array}$ & -.09 & $\begin{array}{c}-.78^{* * *} \\
(.30)\end{array}$ & -.30 \\
\hline \multicolumn{5}{|l|}{ Mother's Characteristics } \\
\hline Immigrant & $\begin{array}{c}.29^{* * *} \\
(.07)\end{array}$ & .11 & $\begin{array}{c}.28^{* * *} \\
(.07)\end{array}$ & .10 \\
\hline Age & $\begin{array}{l}.01 \\
(.04)\end{array}$ & .00 & $\begin{array}{l}.01 \\
(.04)\end{array}$ & .00 \\
\hline Age squared & $\begin{array}{r}-.00 \\
(.00)\end{array}$ & -.00 & $\begin{aligned}-.00 \\
(.00)\end{aligned}$ & -.00 \\
\hline High-School Grad & $\begin{array}{l}.16^{* * *} \\
(.05)\end{array}$ & .06 & $\begin{array}{l}.16^{* * *} \\
(.06)\end{array}$ & .06 \\
\hline Some College & $\begin{array}{c}.23^{* * *} \\
(.06)\end{array}$ & .08 & $\begin{array}{c}.22^{* \star *} \\
(.06)\end{array}$ & .08 \\
\hline College Grad & $\begin{array}{l}.53^{* * *} \\
(.13)\end{array}$ & .18 & $\begin{array}{c}.53^{* * *} \\
(.13)\end{array}$ & .18 \\
\hline Medicaid & $\begin{array}{c}-.15^{*} \\
(.08)\end{array}$ & -.06 & $\begin{array}{c}-.14^{*} \\
(.08)\end{array}$ & -.05 \\
\hline $\begin{array}{l}\text { Attends Religious Services Several } \\
\text { Times/Month }\end{array}$ & $\begin{array}{l}.08 \\
(.06)\end{array}$ & .03 & $\begin{array}{l}.08 \\
(.06)\end{array}$ & .03 \\
\hline Hispanic & $\begin{array}{l}.09 \\
(.08)\end{array}$ & .03 & $\begin{array}{l}.08 \\
(.08)\end{array}$ & .03 \\
\hline Non-White/ Non-Hispanic & $\begin{array}{l}-.28^{* * *} \\
(.09)\end{array}$ & -.10 & $\begin{array}{l}-.28^{* * *} \\
(.09)\end{array}$ & -.10 \\
\hline Lived with Both Parents at Age 15 & $\begin{array}{l}.08 \\
(.06)\end{array}$ & .03 & $\begin{array}{l}.08 \\
(.06)\end{array}$ & .03 \\
\hline Months Known Father & $\begin{array}{l}.00^{* *} \\
(.00)\end{array}$ & .00 & $\begin{array}{l}.00^{*} \\
(.00)\end{array}$ & .00 \\
\hline Lived with Baby's Father at Baseline & $\begin{array}{l}1.19^{\star * *} \\
(.06)\end{array}$ & .44 & $\begin{array}{l}1.17^{\star * *} \\
(.07)\end{array}$ & .44 \\
\hline Male Child & $\begin{array}{l}.04 \\
(.04)\end{array}$ & .02 & $\begin{array}{l}.05 \\
(.04)\end{array}$ & .02 \\
\hline Number of Other Children & $\begin{array}{l}.02 \\
(.02) \\
\end{array}$ & .01 & $\begin{array}{l}.02 \\
(.02) \\
\end{array}$ & .01 \\
\hline
\end{tabular}


Table 4(a): Probit and Bivariate Probit Estimates of the Effect of Poor Child Health on Whether Parents Lived Together at Follow-up ( $n=4011)$ (continued)

\begin{tabular}{|c|c|c|c|c|}
\hline \multirow{3}{*}{ Father's Characteristics } & \multicolumn{2}{|c|}{ Probit } & \multicolumn{2}{|c|}{$\begin{array}{c}\begin{array}{c}\text { Bivariate } \\
\text { Probit }\end{array} \\
\end{array}$} \\
\hline & Coefficient & Marginal Effect & Coefficient & Marginal Effect \\
\hline & & & & \\
\hline Age & $\begin{array}{l}.04^{* *} \\
(.02)\end{array}$ & .02 & $\begin{array}{l}.04^{* *} \\
(.02)\end{array}$ & .02 \\
\hline Age squared & $\begin{array}{r}-.00 \\
(.00)\end{array}$ & -.00 & $\begin{array}{r}-.00 \\
(.00)\end{array}$ & -.00 \\
\hline High-School Grad & $\begin{array}{l}-.02 \\
(.05)\end{array}$ & -.01 & $\begin{array}{r}-.03 \\
(.05)\end{array}$ & -.01 \\
\hline Some College & $\begin{array}{l}-.01 \\
(.06)\end{array}$ & -.01 & $\begin{array}{l}-.01 \\
(.06)\end{array}$ & -.00 \\
\hline College Grad & $\begin{array}{l}.16 \\
(.13)\end{array}$ & .06 & $\begin{array}{l}.14 \\
(.13)\end{array}$ & .05 \\
\hline Hispanic & $\begin{array}{l}-.10 \\
(.13)\end{array}$ & -.04 & $\begin{array}{l}-.10 \\
(.13)\end{array}$ & -.04 \\
\hline Non-White/ Non-Hispanic & $\begin{array}{l}-.07 \\
(.13)\end{array}$ & -.03 & $\begin{array}{l}-.07 \\
(.13)\end{array}$ & -.03 \\
\hline Visited In Hospital at Birth & $\begin{array}{c}.68^{* * *} \\
(.08)\end{array}$ & .26 & $\begin{array}{c}.67^{* * *} \\
(.08)\end{array}$ & .26 \\
\hline Has 1 Child w/ Another Partner & $\begin{array}{c}-.17^{* * *} \\
(.04)\end{array}$ & -.07 & $\begin{array}{c}-.17^{* * *} \\
(.04)\end{array}$ & -.07 \\
\hline Has $>1$ Child w/ Other Partner & $\begin{array}{c}-.39^{* * *} \\
(.08)\end{array}$ & -.15 & $\begin{array}{l}-.39^{* * *} \\
(.07)\end{array}$ & -.15 \\
\hline Log Likelihood & -1828.99 & & -2694.38 & \\
\hline Rho & & & $\begin{array}{l}.27^{* *} \\
(.12)\end{array}$ & \\
\hline
\end{tabular}

*Significant at $10 \%$ level; ${ }^{* *}$ Significant at $5 \%$ level; ${ }^{* * *}$ Significant at $1 \%$ level

Notes: (City) clustered robust standard errors in parentheses; all models include state fixed effects (results not presented). 


\begin{tabular}{|c|c|c|}
\hline & Probit & $\begin{array}{c}\text { Bivariate } \\
\text { Probit }\end{array}$ \\
\hline \multicolumn{3}{|l|}{ Mother's Characteristics } \\
\hline Immigrant & $\begin{array}{l}-.06 \\
(.11)\end{array}$ & $\begin{array}{r}-.06 \\
(.11)\end{array}$ \\
\hline Age & $\begin{array}{l}.02 \\
(.04)\end{array}$ & $\begin{array}{l}.02 \\
(.04)\end{array}$ \\
\hline Age squared & $\begin{array}{l}-.00 \\
(.00)\end{array}$ & $\begin{array}{l}-.00 \\
(.00)\end{array}$ \\
\hline High-School Grad & $\begin{array}{l}-.06 \\
(.08)\end{array}$ & $\begin{array}{l}-.06 \\
(.08)\end{array}$ \\
\hline Some College & $\begin{array}{l}-.08 \\
(.06)\end{array}$ & $\begin{array}{l}-.08 \\
(.06)\end{array}$ \\
\hline College Grad & $\begin{array}{l}-.08 \\
(.10)\end{array}$ & $\begin{array}{l}-.08 \\
(.10)\end{array}$ \\
\hline Medicaid & $\begin{array}{l}.09 \\
(.08)\end{array}$ & $\begin{array}{l}.10 \\
(.08)\end{array}$ \\
\hline Attends Religious Services Several Times/Month & $\begin{array}{l}.09 \\
(.06)\end{array}$ & $\begin{array}{l}.09 \\
(.06)\end{array}$ \\
\hline Hispanic & $\begin{array}{c}-.21^{*} \\
(.12)\end{array}$ & $\begin{array}{c}-.22^{*} \\
(.12)\end{array}$ \\
\hline Non-White/ Non-Hispanic & $\begin{array}{r}-.04 \\
(.08)\end{array}$ & $\begin{array}{l}-.04 \\
(.08)\end{array}$ \\
\hline Lived with Both Parents at Age 15 & $\begin{array}{r}-.01 \\
(.08)\end{array}$ & $\begin{array}{l}-.01 \\
(.08)\end{array}$ \\
\hline Months Known Father & $\begin{array}{r}-.00 \\
(.00)\end{array}$ & $\begin{array}{l}-.00 \\
(.00)\end{array}$ \\
\hline Lived with Baby's Father at Baseline & $\begin{array}{l}-.10 \\
(.08)\end{array}$ & $\begin{array}{l}-.10 \\
(.08)\end{array}$ \\
\hline Male Child & $\begin{array}{c}.15^{* * *} \\
(.05)\end{array}$ & $\begin{array}{c}.15^{\star \star *} \\
(.05)\end{array}$ \\
\hline Number of Other Children & $\begin{array}{c}-.05^{\star *} \\
(.02)\end{array}$ & $\begin{array}{c}-.06^{* *} \\
(.02)\end{array}$ \\
\hline
\end{tabular}

(Continued on next page) 
Table 4(b): Probit and Bivariate Probit Estimates of Poor Child Health ( $n=4011)$ (continued)

\begin{tabular}{|c|c|c|}
\hline & $\begin{array}{c}\text { Probit } \\
\text { Coefficient }\end{array}$ & $\begin{array}{c}\text { Bivariate } \\
\text { Probit }\end{array}$ \\
\hline \multicolumn{3}{|l|}{ Father's Characteristics } \\
\hline Age & $\begin{array}{l}.04 \\
(.03)\end{array}$ & $\begin{array}{l}.04 \\
(.03)\end{array}$ \\
\hline Age squared & $\begin{array}{l}-.00 \\
(.00)\end{array}$ & $\begin{array}{l}-.00 \\
(.00)\end{array}$ \\
\hline High-School Grad & $\begin{array}{r}-.07 \\
(.08)\end{array}$ & $\begin{array}{r}-.06 \\
(.07)\end{array}$ \\
\hline Some College & $\begin{array}{c}-.37^{* * *} \\
(.09)\end{array}$ & $\begin{array}{c}-.36^{* * *} \\
(.08)\end{array}$ \\
\hline College Grad & $\begin{array}{c}-.46^{* * *} \\
(.16)\end{array}$ & $\begin{array}{c}-.47^{\star \star *} \\
(.16)\end{array}$ \\
\hline Hispanic & $\begin{array}{l}.13 \\
(.12)\end{array}$ & $\begin{array}{l}.14 \\
(.12)\end{array}$ \\
\hline Non-White/ Non-Hispanic & $\begin{array}{l}.04 \\
(.12)\end{array}$ & $\begin{array}{l}.04 \\
(.11)\end{array}$ \\
\hline \multicolumn{3}{|l|}{ Identifiers } \\
\hline \# of Ob/Gyns per 10,000 Women in City & $\begin{array}{c}-.03^{* * *} \\
(.01)\end{array}$ & $\begin{array}{c}-.03^{* * *} \\
(.01)\end{array}$ \\
\hline \# of Abortion Providers in County & $\begin{array}{c}-.11^{* * *} \\
(.04)\end{array}$ & $\begin{array}{c}-.12^{\star * *} \\
(.04)\end{array}$ \\
\hline Level III NICU in Birth Hospital & $\begin{array}{l}.07 \\
(.10)\end{array}$ & $\begin{array}{l}.06 \\
(.09)\end{array}$ \\
\hline Log Likelihood & -865.99 & -2694.38 \\
\hline Rho & & $\begin{array}{l}.27^{* *} \\
(.12)\end{array}$ \\
\hline
\end{tabular}

*Significant at $10 \%$ level; ${ }^{* *}$ Significant at $5 \%$ level; ${ }^{* *}$ Significant at $1 \%$ level Notes: (City) clustered robust standard errors in parentheses; all models include state fixed effects (results not presented). 
Table 5(a): Probit and Bivariate Probit Estimates of Poor Child Health on Whether Parents' Relationship Stayed the Same or Improved $(n=3804)$

\begin{tabular}{|c|c|c|c|c|}
\hline \multirow{3}{*}{ Child is in Poor Health } & \multicolumn{2}{|c|}{ Probit } & \multicolumn{2}{|c|}{$\begin{array}{c}\text { Bivariate } \\
\text { Probit }\end{array}$} \\
\hline & Coefficient & Marginal Effect & Coefficient & Marginal Effect \\
\hline & $\begin{array}{l}-.20^{* *} \\
(.10)\end{array}$ & -.07 & $\begin{array}{c}-.72^{*} \\
(.42)\end{array}$ & -.26 \\
\hline \multicolumn{5}{|l|}{ Mother's Characteristics } \\
\hline Immigrant & $\begin{array}{c}.29 * * * \\
(.08)\end{array}$ & .08 & $\begin{array}{c}.28^{* * *} \\
(.08)\end{array}$ & .08 \\
\hline Age & $\begin{array}{l}.01 \\
(.03)\end{array}$ & .00 & $\begin{array}{l}.01 \\
(.03)\end{array}$ & .00 \\
\hline Age squared & $\begin{aligned}-.00 \\
(.00)\end{aligned}$ & -.00 & $\begin{array}{l}-.00 \\
(.00)\end{array}$ & -.00 \\
\hline High-School Grad & $\begin{array}{l}.07 \\
(.05)\end{array}$ & .02 & $\begin{array}{l}.07 \\
(.05)\end{array}$ & .02 \\
\hline Some College & $\begin{array}{c}.20^{* * *} \\
(.06)\end{array}$ & .06 & $\begin{array}{c}.19^{* * *} \\
(.06)\end{array}$ & .06 \\
\hline College Grad & $\begin{array}{l}.52^{* \star *} \\
(.12)\end{array}$ & .14 & $\begin{array}{l}.52^{* \star *} \\
(.11)\end{array}$ & .14 \\
\hline Medicaid & $\begin{array}{l}-.10 \\
(.07)\end{array}$ & -.03 & $\begin{array}{l}-.09 \\
(.07)\end{array}$ & -.03 \\
\hline $\begin{array}{l}\text { Attends Religious Services Several } \\
\text { Times/Month }\end{array}$ & $\begin{array}{l}.13^{* *} \\
(.05)\end{array}$ & .04 & $\begin{array}{l}.13^{* *} \\
(.06)\end{array}$ & .04 \\
\hline Hispanic & $\begin{array}{l}-.05 \\
(.10)\end{array}$ & .02 & $\begin{array}{l}-.06 \\
(.09)\end{array}$ & -.02 \\
\hline Non-White/ Non-Hispanic & $\begin{array}{c}-.21^{* *} \\
(.08)\end{array}$ & -.07 & $\begin{array}{l}-.22^{* * *} \\
(.08)\end{array}$ & -.07 \\
\hline Lived with Both Parents at Age 15 & $\begin{array}{l}.09^{*} \\
(.05)\end{array}$ & .03 & $\begin{array}{l}.09^{*} \\
(.05)\end{array}$ & .03 \\
\hline Months Known Father & $\begin{array}{l}.00^{*} \\
(.00)\end{array}$ & .00 & $\begin{array}{l}.00 \\
(.00)\end{array}$ & .00 \\
\hline Lived with Baby's Father at Baseline & $\begin{array}{c}.36^{* * *} \\
(.06)\end{array}$ & .12 & $\begin{array}{c}.35^{* * *} \\
(.06)\end{array}$ & .11 \\
\hline Male Child & $\begin{array}{l}.05 \\
(.05)\end{array}$ & .02 & $\begin{array}{l}.06 \\
(.05)\end{array}$ & .02 \\
\hline Number of Other Children & $\begin{array}{r}-.01 \\
(.01)\end{array}$ & -.00 & $\begin{array}{r}-.01 \\
(.01)\end{array}$ & -.00 \\
\hline
\end{tabular}

(Continued on next page) 
Table 5(a): Probit and Bivariate Probit Estimates of Poor Child Health on Whether Parents' Relationship Stayed the Same or Improved $(n=3804)$ (continued)

\begin{tabular}{|c|c|c|c|c|}
\hline \multirow{3}{*}{ Father's Characteristics } & \multicolumn{2}{|c|}{ Probit } & \multicolumn{2}{|c|}{$\begin{array}{c}\text { Bivariate } \\
\text { Probit }\end{array}$} \\
\hline & Coefficient & Marginal Effects & Coefficient & Marginal Effects \\
\hline & & & & \\
\hline Age & $\begin{array}{l}.04^{* *} \\
(.02)\end{array}$ & .01 & $\begin{array}{l}.05^{* *} \\
(.02)\end{array}$ & .01 \\
\hline Age squared & $\begin{array}{r}-.00 \\
(.00)\end{array}$ & -.00 & $\begin{array}{r}-.00 \\
(.00)\end{array}$ & -.00 \\
\hline High-School Grad & $\begin{array}{l}-.02 \\
(.05)\end{array}$ & -.01 & $\begin{array}{r}-.02 \\
(.05)\end{array}$ & -.01 \\
\hline Some College & $\begin{array}{r}-.00 \\
(.08)\end{array}$ & -.00 & $\begin{array}{l}.02 \\
(.07)\end{array}$ & -.01 \\
\hline College Grad & $\begin{array}{l}.13 \\
(.15)\end{array}$ & .04 & $\begin{array}{l}.11 \\
(.15)\end{array}$ & .03 \\
\hline Hispanic & $\begin{array}{l}-.12 \\
(.14)\end{array}$ & -.04 & $\begin{array}{r}-.12 \\
(.14)\end{array}$ & -.04 \\
\hline Non-White/ Non-Hispanic & $\begin{array}{l}-.10 \\
(.14)\end{array}$ & -.03 & $\begin{array}{r}-.10 \\
(.13)\end{array}$ & -.03 \\
\hline Visited In Hospital at Birth & $\begin{array}{c}.49^{* * *} \\
(.07)\end{array}$ & .17 & $\begin{array}{c}.48^{* * *} \\
(.07)\end{array}$ & .17 \\
\hline Has 1 Child w/ Another Partner & $\begin{array}{c}-.24^{\star * *} \\
(.06)\end{array}$ & -.08 & $\begin{array}{c}-.24^{* * *} \\
(.06)\end{array}$ & -.08 \\
\hline Has $>1$ Child w/ Other Partner & $\begin{array}{c}-.39^{* * *} \\
(.06)\end{array}$ & -.13 & $\begin{array}{c}-.39^{* * *} \\
(.06)\end{array}$ & -.13 \\
\hline Log Likelihood & -1946.59 & & -2777.52 & \\
\hline Rho & & & $\begin{array}{l}.25 \\
. .17)\end{array}$ & \\
\hline
\end{tabular}

*Significant at $10 \%$ level; ${ }^{* *}$ Significant at $5 \%$ level; ${ }^{* * *}$ Significant at $1 \%$ level

Notes: (City) clustered robust standard errors in parentheses; all models include state fixed effects (results not presented). 


\begin{tabular}{|c|c|c|}
\hline & Probit & $\begin{array}{c}\text { Bivariate } \\
\text { Probit }\end{array}$ \\
\hline & Coefficient & Coefficient \\
\hline \multicolumn{3}{|l|}{ Mother's Characteristics } \\
\hline Immigrant & $\begin{array}{l}-.03 \\
(.12)\end{array}$ & $\begin{array}{l}-.03 \\
(.12)\end{array}$ \\
\hline Age & $\begin{array}{l}.03 \\
(.04)\end{array}$ & $\begin{array}{l}.02 \\
(.05)\end{array}$ \\
\hline Age squared & $\begin{array}{l}-.00 \\
(.00)\end{array}$ & $\begin{array}{l}-.00 \\
(.00)\end{array}$ \\
\hline High-School Grad & $\begin{array}{l}-.06 \\
(.08)\end{array}$ & $\begin{array}{l}-.05 \\
(.08)\end{array}$ \\
\hline Some College & $\begin{array}{l}-.08 \\
(.07)\end{array}$ & $\begin{array}{l}-.08 \\
(.07)\end{array}$ \\
\hline College Grad & $\begin{array}{l}-.08 \\
(.10)\end{array}$ & $\begin{array}{l}-.08 \\
(.11)\end{array}$ \\
\hline Medicaid & $\begin{array}{l}.08 \\
(.08)\end{array}$ & $\begin{array}{l}.09 \\
(.08)\end{array}$ \\
\hline Attends Religious Services Several Times/Month & $\begin{array}{l}.09 \\
(.06)\end{array}$ & $\begin{array}{l}.09 \\
(.06)\end{array}$ \\
\hline Hispanic & $\begin{array}{c}-.25^{\star *} \\
(.13)\end{array}$ & $\begin{array}{c}-.26^{* *} \\
(.13)\end{array}$ \\
\hline Non-White/ Non-Hispanic & $\begin{array}{l}-.05 \\
(.08)\end{array}$ & $\begin{array}{l}-.07 \\
(.08)\end{array}$ \\
\hline Lived with Both Parents at Age 15 & $\begin{array}{r}-.02 \\
(.08)\end{array}$ & $\begin{array}{l}-.01 \\
(.09)\end{array}$ \\
\hline Months Known Father & $\begin{array}{l}-.00 \\
(.00)\end{array}$ & $\begin{array}{l}-.00 \\
(.00)\end{array}$ \\
\hline Lived with Baby's Father at Baseline & $\begin{array}{l}-.14 \\
(.09)\end{array}$ & $\begin{array}{l}-.13 \\
(.09)\end{array}$ \\
\hline Male Child & $\begin{array}{l}.15^{\star *} \\
(.06)\end{array}$ & $\begin{array}{l}.16^{* *} \\
(.06)\end{array}$ \\
\hline Number of Other Children & $\begin{array}{c}-.06^{* *} \\
(.02)\end{array}$ & $\begin{array}{l}.06^{* *} \\
(.03)\end{array}$ \\
\hline
\end{tabular}

(Continued on next page) 
Table 5(b): Probit and Bivariate Probit Estimates of Poor Child Health $(n=3804)$ (continued)

\section{Father's Characteristics}

\begin{tabular}{cc} 
Probit & $\begin{array}{c}\text { Bivariate } \\
\text { Probit }\end{array}$ \\
\hline Coefficient & Coefficient \\
\hline
\end{tabular}

Age

.03

(.03)

.04

Age

Age squared

$$
-.00
$$

$(.00)$

$-.00$

High-School Grad

$-.07$

(.07)

$-.38^{* * *}$

(.08)

$-.37^{* * *}$

Some College

$-.47^{* * *}$

(.16)

$-.47^{* * *}$

College Grad

.12

(.14)

.12

Hispanic

.05

(.11)

(.14)

Non-White/ Non-Hispanic

.06

(.11)

Identifiers

\# of Ob/Gyns per 10,000 Women in City

\# of Abortion Providers in County

$-.03^{* * *}$

$-.03^{* * *}$

(.01)

(.01)

$-.13^{* * *}$

$-.13^{* * *}$

(.04)

(.04)

Level III NICU in Birth Hospital

.05

.05

(.10)

(.10)

Log Likelihood

$-831.33$

$-2777.52$

Rho

${ }^{*}$ Significant at $10 \%$ level; ${ }^{* *}$ Significant at $5 \%$ level; ${ }^{* * *}$ Significant at $1 \%$ level

Notes: (City) clustered robust standard errors in parentheses; all models include state fixed effects (results not presented). 
Figure 1: Probability of Relationship Status Improving or Remaining the Same, by Income and Child Health
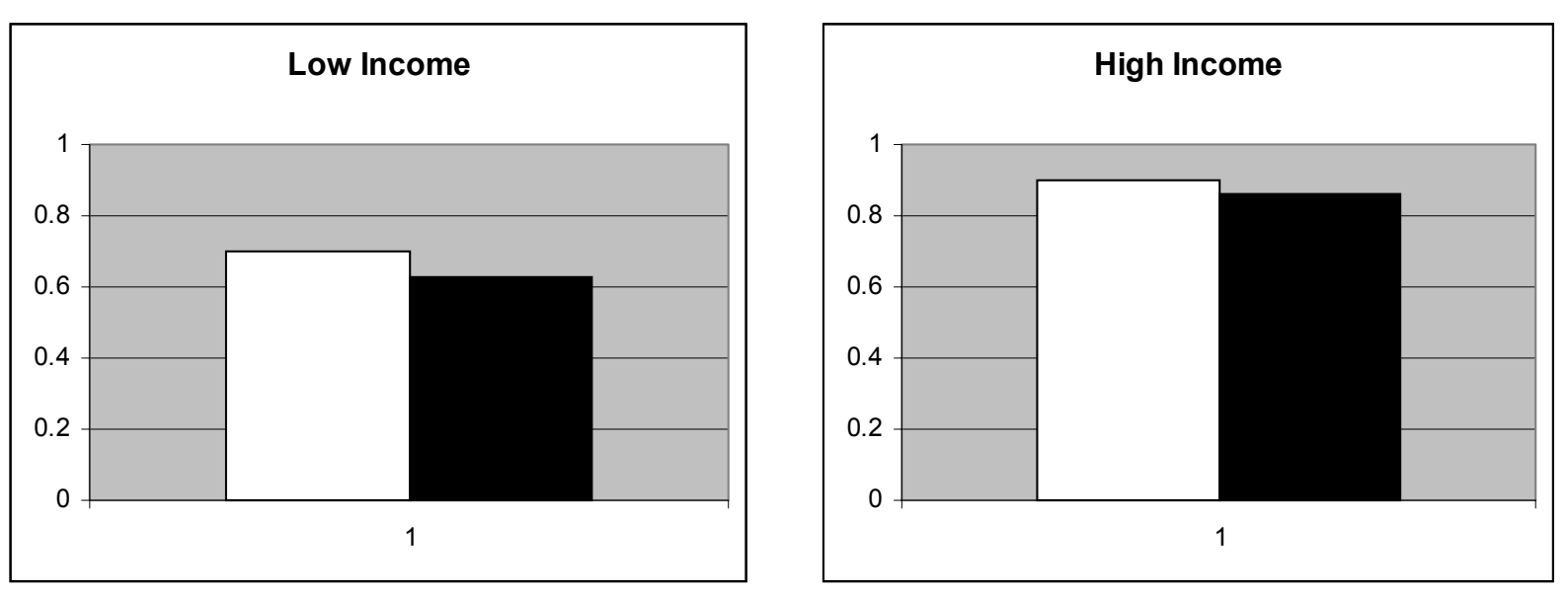

$\square$ Child Does Not Have a

Health Problem

Child Has a Health Problem 


\section{Appendix Table 1}

\section{Tests for Condition \#1: Identifiers are Significant Predictors of Poor Child Health}

Chi-Square Statistics for Joint Significance $(\mathrm{df}=3)$

\begin{tabular}{|c|c|c|c|c|}
\hline \multirow[b]{3}{*}{$\begin{array}{l}\text { Ob/gyns, } \\
\text { abortion } \\
\text { providers, and } \\
\text { NICUs }\end{array}$} & \multicolumn{2}{|c|}{ Results for Tables 4(a), 4(b): } & \multicolumn{2}{|c|}{ Results for Tables $5(a), 5(b)$ : } \\
\hline & Probit & Bivariate Probit & Probit & Bivariate Probit \\
\hline & $20.70^{* * *}$ & $22.18^{* * *}$ & $21.60^{* * *}$ & $20.97^{* * *}$ \\
\hline
\end{tabular}




\section{Appendix Table 2}

Tests for Condition \#2: Identifiers are Excludable from Relationship Equation

Chi-Square Statistics for Joint Significance $(\mathrm{df}=2)$

\begin{tabular}{lcc}
\hline & $\begin{array}{c}\text { Parents Lived Together at } \\
\text { Follow-up }\end{array}$ & $\begin{array}{c}\text { Relationship Improved or } \\
\text { Stayed the Same }\end{array}$ \\
\cline { 2 - 3 } Ob/gyns and Abortion & .60 & 1.46 \\
Ob/gyns and NICU & $\mathrm{p}=.74$ & $\mathrm{p}=.48$ \\
& .11 & 1.22 \\
NICU and Abortion & $\mathrm{p}=.95$ & $\mathrm{p}=.54$ \\
& .01 & 1.01 \\
& $\mathrm{p}=.99$ & $\mathrm{p}=.60$ \\
\hline
\end{tabular}

